Article

\title{
Translation as a Communication Strategy in Representing National Culture
}

\author{
Aizhan Akkaliyeva ${ }^{1, *}$, Baktigul Abdykhanova ${ }^{2}$, Lyazat Meirambekova ${ }^{3}$, Zhanar Jambayeva ${ }^{4}$ \\ and Galiya Tussupbekova ${ }^{5}$ \\ ${ }^{1}$ Department of Translation Studies, L. N. Gumilyov Eurasian National University, 010000 Nur-Sultan, Kazakhstan; \\ E-Mail: akkalieva.aizhan@mail.ru \\ 2 Department of Foreign and Russian Philology, Shakarim State University of Semey, 070000 Semey, Kazakhstan; \\ E-Mail: abdychanovab@mail.ru \\ ${ }^{3}$ Department of Foreign Languages, Faculty of International Relations, L. N. Gumilyov Eurasian National University, \\ 010000 Nur-Sultan, Kazakhstan; E-Mail: Imeyrambekova@mail.ru \\ ${ }^{4}$ Department of Theoretical and Applied Linguistics, L. N. Gumilyov Eurasian National University, 010000 Nur-Sultan, \\ Kazakhstan; E-Mail: sgpi@mail.ru \\ ${ }^{5}$ Department of Kazakh Language and Literature, Shakarim State University of Semey, 070000 Semey, Kazakhstan; \\ E-Mail: autovna67@mail.ru \\ * Corresponding author
}

Submitted: 31 July 2020 | Accepted: 15 September 2020 | Published: 14 January 2021

\begin{abstract}
The linguistic trinity policy, which has been implemented in Kazakhstan since its independence in the 1990s, is aimed at integrating translation into global processes. Kazakh-Russian bilingualism, caused by the historical and geopolitical proximity of the two countries, is now turning into trilingualism, joining up with English as the dominant language for international communication. Literary translation as a part of cross-cultural communication is also involved in social inclusion processes, contributing to the exchange of cultural values and a better understanding of modern multilingual Kazakhstani society. This article focuses on the issue of presenting Kazakh literature in translation through a mediating language and the research involves an analysis of culture-related lexemes as representations of a nomadic lifestyle in the mirror of intercultural communication. The authors highlight cultural and linguistic aspects of Kazakh transmitted from the mediatory Russian into the target English. Based on a review of previous findings on indirect literary translation, this article discusses whether a mediating language affects the inclusion of Kazakh culture in the globalization process.
\end{abstract}

\section{Keywords}

bilingualism; culture-related realia; intercultural communication; literary translation; national literature; translation

\section{Issue}

This article is part of the issue "Social Inclusion and Multilingualism: The Impact of Linguistic Justice, Economy of Language and Language Policy" edited by László Marácz (University of Amsterdam, The Netherlands / L. N. Gumilyov Eurasian National University, Kazakhstan) and Zsombor Csata (Babeș-Bolyai University, Romania / Hungarian Academy of Sciences, Hungary).

(C) 2021 by the authors; licensee Cogitatio (Lisbon, Portugal). This article is licensed under a Creative Commons Attribution 4.0 International License (CC BY).

\section{Introduction}

Literature and translation are two connected spheres, the former being able to migrate into other cultures via translation. Even though literary translations have often been considered inferior compared to their sources, new literary forms and ideas, borrowed from a foreign lan- guage culture through translation, have contributed to the development of a national literature moving in new directions (Woodsworth, 2013, p. 72).

In the context of globalization, literary translation can serve as an indicator of the relationships of "minordominant" cultures, when the translation is carried out through an intermediary language. In this regard, the 
role of the indirect translation expands as it becomes a connecting tie between an original text and a target reader. Besides, translation either direct or indirect is a factor leading to greater diversity and thus a contributor to the internal differentiation of national literature (Levy, 1974).

In the modern science of translation, there is still no definite concept characterizing indirect translation. On the one hand, there is a clear negative attitude to this type of translation, reflected in UNESCO's request that translation be made from the original language (Pieta, 2014). On the other hand, it is necessary that, as a means of communication between peripheral and dominants cultures, the issue of indirect translation be kept sharp and twofold (Pieta, 2017; Ringmar, 2007). Indirect translation makes possible the dissemination of minor literatures worldwide. In this case, indirect translation is a more efficient means for the inclusion of cultural products from peripheral cultures (Witt, 2017). Furthermore, there is a need to study not only translated texts but also cultures as, within the process of literary translation, the phenomenon of cultural asymmetry is observed. To detect these asymmetries, an analysis of the economic and political processes in the source and target society could increasingly reveal the constraints in the production and reproduction of texts (Lambert, 2006).

The literature of the former soviet republics attracts little attention among western scholars, admits Chernetsky (2011) when considering Ukrainian literature in translation. Kazakh literature has shared the same fate and the history of its development and translation asks for rigorous study.

Generally, Kazakh literature is considered to be peripheral and its translation exemplifies an interesting model of a mediating relationship between national and world literatures through the Russian languange. The striking point in these relations is that Kazakh-Russian bilingualism has become part and feature of the national literature and culture, conditioned by historical and geopolitical events. One of the manifestations of bilingualism in fiction is the mixture of multilingual elements.

The change of cultural and civilization paradigms at the turn of the last two centuries, the structuring of a new geopolitical and cultural-spiritual space, has led to a new stream of studies that contributed to the disclosure of the phenomenon of creative bilingualism (Bakhtikireeva, 2005), that is, a perception of the world by bilingual writers as a "linguistic" world (Tumanova, 2012). It has been argued that the linguistic situation in modern Kazakhstan differs significantly from that of the Soviet period concerning everyday interaction and in literature. It is bilingualism that supports intercultural dialogue and contributes to the formation of ethnic, social, ideological, and communicative tolerance in modern Kazakhstani community (Tuksaitova, 2007).

François, Marácz, Pokorn, and Kraus (2018, p. 103) state that translation, like other communication strate- gies, can be used to favor mobility and inclusion in global communication. In this regard translation of literary works via mediating language can be accepted as a creative transnational interaction and contribute to the policy of linguistic diversity and linguistic justice.

As has been established, for a long time, in all of the republics of the former Soviet Union, the study of Russian as a state-forming language attracted more attention, while other national languages were relegated to the background due to their limited use in various spheres of society.

Authors from the indigenous Kazakh nation used more Russian in their work, and this linguistic situation has suffered significant changes since the emergence of newly independent states due to new understandings of the role of native languages and changes in the linguistic consciousness of authors. Kazakhstani writers more actively use the potential of their native language and culture, or the titular language of the ethnic group, when describing their surrounding reality. As a result, the use of Kazakh-Russian bilingualism - with the predominance of the Kazakh language-and Russian-Kazakh bilingualism-with the predominance of the Russian language-has become widespread in Kazakhstan. This has regularly been an object of interest for Kazakh linguists (Amalbekova, 2010).

So, the problem of literary translation from and into Kazakh should be approached from the point of view of multilingualism or, to be more precise, bilingualism as, in the system of translation in Kazakhstan and Central Asia, the Russian language acts as a polyfunctional means of communication, serving as a source, mediating, and intra-national language (Khasanov, 1987).

The history of Kazakh translation is closely connected and intertwined with the Soviet science of translation. The process of formation of the canons of Russian-Kazakh literary translation stretches back to tsarist times, when trade, political and diplomatic relations were established. At the time of the Soviet regime, translation of Kazakh literature was completely under the control of censorship. This process is a characteristic of the national literature of all post-Soviet republics. As Witt (2017) argues, literary translation in the Soviet Union, where a totalitarian regime ruled, attracts little academic attention, though the practices that existed in that period might 'highlight the question of translation and power' and be a brilliant example of 'interlinear translation in the Soviet context.' Literary translation in the former republics of the Soviet Union was implemented with the help of trots or podstochniki (indirect translation) and more often implied culture planning, according to G. Toury (Witt, 2011).

Russian scholars considered indirect translation as a factor contributing to the development of the Soviet school of poetic translation, in spite of the fact that the mass character of translations from national languages into Russian lowered the quality of "the product" (Nikonova, 2008). 
With regard to the Kazakh history of translation, by the end of the 1990s, a cohort of bilingual native speaker translators who had fully mastered two languages had formed in Kazakhstan. Kazakhstan's literary translation was already moving to a new level of quality at that moment: This became an era of conceptual translation and translation-interpretation (Bakhtikireeva, 2009).

In this article, we examine the issue of indirect translation in the context of the equivalence of cultural and linguistic realias representing the Kazakh culture. We emphasize the fact that, in spite of the presence of the mediating language, modern standards of literary translation allow the transposition of both artistic and national specifics of a work of fiction. Moreover, the phenomenon of Kazakh-Russian or Russian-Kazakh bilingualism has contributed to lessening semantic losses during the process of indirect translation as a great range of vocabulary in Kazakh and Russian is based on notions that embrace bilingualism.

\section{Methods and Materials}

Russian and English variants of the translation of the novel $A q$ Boz Yui by the well-known Kazakh writer Smagul Yelubay (2008) were used as empirical material for our research. The novel was translated into Russian by Kazakh translator L. Kosmukhamedova and the English translation was performed by American translator K. Fitzpatric, known for her translations of Soviet authors.

The main material, including cultural and linguistic realias, was subjected to linguistic and statistical analysis using comparative and statistical methods. In total, we collected 500 lexical units, referred to as culture-specific terms, but for this article only a minor part of the lexemes have been considered, constituting about 100 lexical units.

The method of linguistic analysis makes it possible to reveal different methods of transposing realias into the target language through the interlinear language and to evaluate the losses and gains in the process of interlingual interaction. The use of statistical analysis allows us to establish the level of linguistic loss and, thus, assess the role of the interlinear language in the process.

\section{Discussion}

Aq Boz Yui is composed of three parts depicting the most sorrowful events in the history of Kazakhstan in the 1930s, the Holodomor. Conquest (1986) claims that the Holodomor, the disastrous famine, was caused by the failed policies of the Soviet government on the territories of Ukraine, Kazakhstan, and other soviet republics. Human losses in Kazakhstan were staggering, with nearly seven million people dying in the horrific famine. Historians argue that it might have been ethnic genocide (Kotkin, 2014). The novel arouses interest not only through its linguistic content but also through the descriptions of the social and cultural events which took place during this historical period.

The author opened up the world in which Kazakhs lived at that time, with its everyday lifestyles, language, and unique system of tribal order having been destroyed by the new political formation (Zhaksylykov, 2013). It is essential to reconsider historic events and recover our ethnic roots to preserve our national identity and to interact with other cultures. It should be noted that in the 1980 s, when Yelubay was creating this work, the topic of the Holodomor in former soviets was banned.

As far as the linguistic features of the novel are concerned, the range of specific vocabulary used by the author is worth mentioning. As Nida (1964) asserts, different languages display different concentrations of vocabulary; this depends on the cultural focus of the given ethnos in the matter under consideration. The ethnos of the Nuers of the Sudan is known for having a great number of terms relating to cattle, the Arabs have an intensive vocabulary for camels, and the same trend is found in the Kazakh language. In this article we will discuss the problem of translatability and ways of finding equivalents to these cultural realias in the context of indirect translation.

Any time the issue of equivalence is considered, either structural or dynamic, we should keep in mind three types of relatedness, 'as determined by the linguistic and cultural distance between codes used to convey the messages' (Nida, 1964, p. 160).

In the case of Kazakh-English translations, we have two different languages and cultures, though the existence of the intermediary language, Russian, plays a significant role in making intercommunication more accessible. Regarding this, it is agreed that, according to some authors (Catford, 1965; Fawcett, 1997) the semiotic approach to solving the problem of cultural losses or untranslatability is evidently favorable. It allows the translator not only to search for equivalence of meaning but to go deeper into semantic content and the pragmatic context.

The lexical system of the Kazakh language is characterized by the presence of different synonymous notions related to a general one, e.g.: There are more than 13 notions to indicate male representatives of various ages, more than 20 words to denote dairy products, and up to 25 synonyms for the term "species" (Belger, 2009). The existence of hyponymic structures in the source language can cause difficulties for translators, and we provide linguistic comments on the use of these specific terms.

The bulk of cultural terms from the novel have been subdivided into four groups:

1. Cattle nomination

2. Russian and Kazakh borrowings

3. Religion-related notions

4. Culture-specific terms for items of clothing 
The terms related to livestock were few in the novel but, as they were more specific in structure and semantics, they were thought to present interest in terms of translation.

\subsection{Cattle Nomination}

In general, Kazakhs employ about one hundred notions for denoting camel but in the framework of our research, we have analyzed the use of twenty notions. These include nar (single-horned), bura (two-humped sire), ulek (purebred camel), kaspak (half-bred from singlehorned sire and two-humped female), zhelbaya (camel stallion), zhalbay (with humps in different directions), aruana (single-horned female camel), ingen (milking cow), atan (emasculated), arvan (a pack camel breed), kaiyma (primiparous camel), buyrshyn (young stallion), bota (calf), tailak (over one year old), tumsa (young female), zhampoz (a kind of zhalbay ), maya (aruana offspring), amongst others. In the winter, all the camels are called "thick-woolen," but in summer they are kara kaiys tuie, which means "black as rawhide." In autumn they are referred to as bozdakty tuie, where bozdak means "undercoat left after the spring wool cutting." This list can be enlarged with the following lexemes: lek (singlehorned sire), narsha (three year old), kunazhyn (a species between three and four years old), eki tysty (a four year-old, literally meaning "two-teethed"), and tort-tisti (a full-grown adult, literally "four-teethed"). The lexeme aruana can be widened to describe not just a onehumped camel, but a purebred female, with thick wool on the nape and a lush long tail.

Having such a variety of lexemes in Kazakh produces many obstacles for translators (Belger, 2009). But in both stages of translation, camel-related terms preserve their main semantic meaning by the use of explanatory translation.

Cattle-nominating specific terms represent the Kazakh nomadic lifestyle they followed before the establishment of the Soviet regime in the Kazakh steppes. Camels and horses comprised a significant part of the workforce in the nomadic household, so the fact that Kazakh authors address the images of animals in their works is logically assumed.

In Yelubay's novel, the camel is not the central figure, but the author often assigns a significant role to its image. The camel for the Kazakhs, who led a nomadic lifestyle up until the 1920s, was an important part of everyday life and served as a means of transportation during their migration from their winter to their summer settlements. So, there are many detailed descriptions of camels' behavior in works of fiction, even their individual traits of character are depicted colorfully.

In the novel, we deal mostly with generic names. When translating into Russian, the use of the lexemes verblyud, nar, and dromader prevail in the translation of Kazakh hyponyms. There are some cases when the meaning of specific words denoting "camels" has been trans- formed through transliteration or by adding explanatory notes. Here are some examples of this:

Kazakh: Shoıynqara túksiip sıdań-sıdań jelgen shı borbaı aruana, ingen, maıa, qunanshalarǵa suzile qaraıdy. Bul Shoıynqaranyń úiri edi (Yelubay, 2008, p. 35 , emphasis by the authors)

Russian: Sholynkara, obrosshı klochmı sherstı tak, chto ona svisala I s mordy, totchas oshshetınılsıa, prıstalno, v upor razglıadyvaıa zamelkavshıh pered ego glazamı, tonkonogıh verblıýdıc $s$ oblezlymı lıajkamı, odnogorbyh I dvýgorbyh, molodyh ı ne sovsem molodyh. Eto bylo ego stado, kotorogo vse leto on byl polnovlastnym vojakom. (Yelubay, 2009, p. 26, emphasis by the authors)

English: Shoinqara with overgrown clumps of fur even hanging from his mouth, bristled, stared fast at the slender-legged female camel with bare thighs, onehumped and two-humped, young and not so young, flashing before his eyes. (Yelubay, 2016, p. 46, emphasis by the authors)

In the English translation, the most common method of translation used is explanatory, whereby a term describing a specific kind or breed of a camel is transposed through attributive or nominative word structures: slender-legged female camel with bare thighs; onehumped and two-humped; young and not so young.

Here is an example of an excerpt describing a huge black camel, which serves as a character in the plot of the novel. The camel was named Shoinqara; the name of the camel carries a semantic load in a pragmatic sense and, therefore, requires clarification. If translated literally, it means "as black, as coal and mighty." The camel symbolizes the "black" power inherent in the common working people. Besides this, in Asian cultures, the camel symbolizes obedience as it easily kneels before being loaded (Skrobonja et al., 2001). The death of the camel on the grave of one of the respected and honored citizens among the Kazakhs symbolizes the fall of the old nomadic style under the ruthless and heavy burden of the socialist system.

The camel in the life of the Kazakhs was not only a means of transportation but also a form of exchange or currency. In the years of famine, people went to neighboring countries in search of work and food and for their work, they got camels. It should be acknowledged that the presence of a camel in the economy of nomads meant a secure and comfortable life. In one episode depicted in the novel, we meet with various names of camels, denoting the breed and age of the animals:

Kazakh: Pirimkúl jylyna bir túıe alasyń deıdi eńbek aqyńa. Sonda, baı bularǵa keleniń ishindegi eń jaman qotyr taılaq pen qatpa maıany beredi. (Yelubay, 2008, p. 74, emphasis by the authors) 
Here, the words qotyr and qatpa express negative meaning, and tailaq denotes a young camel over one year old, and maya denotes a camel of high breed.

Russian: Obeshshal on Daý-ape za rabotý po verblıýdý v god. Dva goda mat s synom paslı baıskıh verblıýdov, a potom reshılı vernýtsıa na rodıný ı poprosılı u baı raschet. Tot vybral ım v tabýne parshıvogo godovalogo verblıýjonka ı starýıý oblezlýıý verblıýdıcu (Yelubay, 2009, p. 55).

English: The bay was called Pirimkul. He promised Dau-apa a camel per year for her work. For two years, the mother and son pastured the bay's camels and then decided to return to their homeland and asked for the bay to settle up. He selected a lousy yearling camel and an old mangy female camel out of the herd (Yelubay, 2016, p. 97, emphasis by the authors)

In our opinion, in the Russian text the adjectives parshivyi and staraya oblezlaya (Ozhegov, 2012) were being used to express some negative characteristics of camels and to successfully cover the cultural loss of the specific terms.

As for the English text, the expressive attributes lousy yearling and old mangy female camel also serve to represent the dramatic effect of the situation, though in the source language the term maya particularly implies a high-quality camel.

In one of the excerpts from the novel, people drive the camels using the word Oisylqara. It was translated into Russian and English literally and for the target readers, it may sound only like an authentic name or exclamation; however, it has an implicit meaning denoting the patron saint of camels in Kazakh mythology. An explanation is given a text footnote in the Russian translation, and in the English text, it is introduced in the ethnographic glossary for readers at the end of the novel.

This short name can refer readers to the pre-Islamic period in the history of the nomads when they were thought to have followed a cult of ancestors and animals (Nurgaliyeva, Tastaeva, Baibulsinova, \& Serikova, 2017, p. 151).

Kazakh: Káni, turǵyzshy endi! Shý, Oısyl-qara! (Yelubay, 2008, p. 33, emphasis by the authors)

Russian: Nu-ka, podymı ego teper! Chý, Oısylkara! (Yelubay, 2009, p. 25, emphasis by the authors)

English: Go on now, raise it up now! Chu, Oysylkara! (Yelubay, 2016, p. 45, emphasis by the authors)

Thus, all 25 lexemes used in the context of the novel to refer to livestock were mostly transposed with the help of an explanatory translation meaning the specific notions and hyponyms were lost in translation.

\section{Russian and Kazakh Borrowings}

One of the features of novels representing historical bilingualism in the works of Kazakh writers is a wide range of Russian borrowings; some of them are still used in Kazakh while others have become archaic. There are some notions that refer to Soviet nomenclature. This stock of words is a valuable source of information about the linguistic interaction between cultures under the influence of political and social processes. We have analyzed 50 Russian borrowed words in the original text and 120 Kazakh borrowings in the Russian translation. Almost all of the borrowings were found in indirect translation in transliterated form.

Most of the Russian borrowings in the original text are used in a distorted way: Kampeske is a distorted version of a Russian word for "confiscation," introduced at the time of the Soviets and turning out to be a tragedy for nomads. Arystabay is how Kazakhs pronounce the Russian word arestovannyi, which means arrested. It refers to people who were arrested by the Soviet authorities following denunciation by some neighbors or those who were from prosperous clans.

Kallektip is a distorted word form of "collective," a political term used to describe the form of social management introduced by the Soviets. Tabarysh-tovarischmeans comrade and is a widely used form of address in the former Soviet Union. Milisakhan is how Kazakh people pronounce militia or police. Atkashevka is a distorted form of the historic term "otkochevka," which denotes the process when local nomads, being afraid of the harsh policies of the Stalinist government, tried to escape to neighboring countries. Komones is a distorted form of the word "communist." Some of these words are still found in their distorted forms in the speech of, mostly elderly, Kazakhs.

The borrowings from Kazakh are also widely used in the Russian language and successfully exploited by bilingual writers in their work to achieve expressiveness.

The lexemes like jigits, koshma, chapan, aksakal, aul, saksaul, baibishe, tokal, yurt, have been successfully transposed into the English translation of the novel. These lexemes from the original work, as culture-relating words in English translation, are presented in their initial forms, so they are translated through calque or transliteration, and a footnote explanation is provided, for example:

Kazakh: Auldyn' bas kotergen aqsaqal, qarasaqaldary Shariptin' yuinde eken (Yelubay, 2008, p. 26, emphasis by the authors)

Russian: Solidnyie muzhi aula, aksakaly, vossedali v yurte Sharipa (Yelubay, 2009, p. 18, emphasis by the authors)

English: The prominent men of the aul, the aksakals, sat solemnly in Sharip's yurt (Yelubay, 2016, p. 3, emphasis by the authors) 
The translation of the two identical in structure words is different: the nouns aqsaqal and qarasaqal, used to indicate age (literally, aqsaqal is "white-bearded" and means "old man," qarasaqal is "black-bearded" and indicates a young, not aged, man). A black beard is recognized in Kazakh culture as a sign of a real man. Qarasaqals participated in the solution of difficult issues in nomadic settlements and were treated as "followers" of the elders (Kaliev, 2014, p. 339). In Russian, the lexeme aksakal has become a common borrowing, but the lexeme qarasaqal, due to the lack of such a concept in the Russian language, has been transposed through an explanation into the attributive construction "prominent men."

\section{Religion-Related Notions}

Religious terms are not numerous, but they perform an expressive role in the original work, portraying the main characters, and also providing additional information about the life of nomads. The total number of religious terms considered in the article is 30 . Many of the presented realias referring to religious traditions and rituals are outdated, and it requires a more careful approach when translating them in order to preserve the style of the historical time, for example:

Kazakh: Qaıyp molda bir kese sýǵa duǵa oqyp dem salyp, bólek eki úıde otyrǵan kúıý men qalyndyqqa rızashylyǵyn bildirip, álgi kesedegi dýaly sýdan bir urttam ishýge jiberdi. (Yelubay, 2008, p. 47, emphasis by the authors)

Russian: Vecherom byl proveden obrád neke kıý. Kaıyp mýla osvátıl molıtvoı vodý v chashe, kotorýú jenıh ı nevesta doljny bylı ıspıt, vyrajaıa tem samym soglasie na brak. (Yelubay, 2009 p. 44, emphasis by the authors)

English: In the evening, the religious ritual known as neke-kiyu was performed. The kaysh-mullahblessed the water in the chalice with a prayer. (Yelubay, 2016 p. 78, emphasis by the authors)

The first lexeme molda in the source text denotes "a Muslim religious teacher or leader" and so it is transposed correspondingly as mulla in Russian and mullah in English. The next highlighted notion dem salu is ethnographic and literally means "to put breath" or "to cast a spell." It is a kind of ritual when a mullah says a prayer over a cup of water as if to sanctify an action or anything else. In the Russian text of the translation, the given extract was presented as an interpretation and a new Kazakh realia was introduced in the translation neke-kiyu, which denotes a religious wedding ceremony. The term in its initial form was transposed into the target text.

A large number of religion-related terms are not considered to be culturally specific as there are adequate equivalents in the target language.
Thus, all religion-related notions keep their original forms in both translated texts and in most cases were followed by explanatory notes in the form of footnotes.

\section{Culture-Specific Terms for Items of Clothing}

The novel under consideration is a historical drama and most of the realia are archaisms. There may be reference to items of clothing worn by nomads. These culture-specific terms may be interesting from the aspect of translating non-equivalent vocabulary. We have analyzed more than 25 units of lexemes for clothing, for example:

Kazakh: Basynda úkisi bulǵaqtaǵan kámshát bórik, ústinde qyrmyzy kámzol. Ash belin túrmemen qynaı baılaǵan. (Yelubay, 2008 p. 9, emphasis by the authors)

Russian: Ona v krýgloı bobrovo shapochke, puh filına klonıtsá Iz storony $v$ storoný na veterke, krasny shelkovyı kamzol v talı týgo perehvachen ızáshno zastejkoı. (Yelubay, 2009 p. 8, emphasis by the authors)

English: She was wearing a round beaver cap, and the owl sewn onto its crown waved in the breeze. Her red silk camisole was held snugly to her slender waist with a fine clasp. (Yelubay, 2016, p.10, emphasis by the authors)

Non-equivalent vocabulary representing items of women's clothing-kamshat boryk, kyrmyzy kamzol-are translated through explanation with the addition of attributive lexemes indicating the material and style of the clothing. For example, the image of a boryk is revealed as 'a round beaver cap.' But the Kazakh lexeme kamsole does not coincide in meaning with the English equivalent "camisole." In Kazakh, kamsole is 'a plush or velvet item of women's clothing without a collar and sleeves, worn over a dress' (Syzdykova \& Khusain, 2001, p. 488), while "camisole" in English, according to the Cambridge dictionary, is a 'short garment worn underneath a sheer bodice to conceal the underwear' or a 'woman's negligee jacket' (Camisole, n.d.).

With other examples of items of clothing, the strategy of transliteration prevails, with added explanatory notes.

Other than the culture-specific terms discussed above, there are more than 50 examples of lexical units in the form of phonetic inclusions or vocatives (jeneshe, apatai, koke), interjections expressing emotions (oibay, kotek), belonging to the most effective speech means of expressing emotions based on non-normativity and which are common in Kazakh-Russian literary texts. Such words are justified in the text and can be considered elements of internationalization, or special inter-language expressiveness techniques (Kopylenko \& Akhmetzhanova, 
1990, p. 162). None of the presented vocabulary was lost while being translated into the target language, being transposed adequately through transliteration, explanatory translation or word-for-word translation.

\section{Conclusion}

The problem of indirect translation has not been adequately covered in local research and requires further study. The linguistic situation, represented by bilingualism in Kazakhstan and Soviet censorship in the past, has determined the indirectness of literary translation. In this regard, the issue of adequacy and equivalence of semantics has been highlighted in the context of correlation and linguistic compliance in this study.

A long historical interrelationship between Kazakh and Russian cultures and languages has brought about unique linguistic phenomena in the form of some culturerelated lexemes being equally found in both languages.

A comparative study of two translations of the original literary work in the Kazakh language has revealed a variety of culture-specific terms relating to different spheres of nomadic life presented in the novel as a historical reality.

The Kazakh language is characterized by a wide range of specific vocabulary, which produces linguistic obstacles for translators when searching for counterparts. However, the interposition of the mediating Russian language allows for the transposition of the specific realia without semantic losses.

So, the historical interaction of the Russian and Kazakh languages has provided a high level of literary translation and shown a low degree of semantic loss in the translation of culture-specific terms. Besides this, the close interrelationship of the two neighboring cultures and languages has fostered a special linguistic phenomenon of bilingual creativity, whereby domestic authors-bilinguals-successfully use the linguistic means of both languages in their work.

To conclude, eighty percent of all lexical units considered in the analysis were transposed adequately in both translations needing only some alterations. The type or degree of alteration depended on the specific nature of the lexeme in question. Transliteration with explanatory footnotes was the prevailing method of translation both into Russian and English.

Thus, in modern terms of global interaction, we consider that the presence of the interlinear language in literary translation is the most beneficial way of displaying national culture and literature to the wider world.

\section{Acknowledgments}

We would like to express our sincere gratitude to Dr. László Marácz and Professor M. Amalbekova for their valuable suggestions during planning and development of this research.

\section{Conflict of Interests}

The authors declare no conflict of interests.

\section{References}

Amalbekova, M. B. (2010). Fenomen bilingval'noy lichnosti publitsista (lingvokulturnyi I sopostavitel'nyi aspecty) [The phenomenon of the bilingual personality of a publicist (linguo-cognitive and comparative aspects)] (Unpublished Doctoral dissertation). L. N. Gumilyov Eurasian National University, Nur-Sultan, Kazakhstan.

Bakhtikireeva, U. M. (2005). Tvorcheskaya lichnost': Natsional'nyi russkoyazychnyi pisatel' I osobennosti ego russkogo khudozhestvennogo teksta [A creative bilingual personality: National Russian-speaking writer and features of his Russian literary text]. Moscow: Triada.

Bakhtikireeva, U. M. (2009). Perevodovedenie v Kazakhstane, Chast' 1 [Translation studies in Kazakhstan, Part 1]. Moscow: Tezaurus.

Belger, G. (2009). Kazakhskoye slovo. Izbrannoye: Esse, romany [The Kazakh word. Selected: Essays, novels]. Almaty: Vox Populi.

Camisole. (n.d.). In Cambridge online dictionary. Retrieved from https://www.dictionary.com/ browse/camisole?s=t

Catford, J. C. (1965). A linguistic theory of translation. London: Oxford University Press.

Chernetsky, V. (2011). Nation and translation: Literal translation and the shaping of the modern Ukrainian culture In B. J. Baer (Ed.), Contexts, subtexts and pretexts: Literary translation in Eastern Europe and Russia (Vol. 89, pp. 33-55). Amsterdam: John Benjamins.

Conquest, R. (1986). The harvest of sorrow: Soviet collectivization and the terror-famine. Oxford: Oxford University Press.

Fawcett, P. (1997). Translation and language: Linguistic theories explained. Manchester: St. Jerome Publishing.

Kaliev, B. (2014). Qarasaqal [Blackbeard]. In Tolkovyi slovar' kazakhskogo yazyka [The explanatory dictionary of the Kazakh language]. Almaty: Almaty Institute of State Language Development.

Khasanov, B. N. (1987). Kazakhsko-russkoye dvuyazychie [Kazakh-Russian bilingualism]. Alma-Ata: Nauka.

Kopylenko, M. M., \& Akhmetzhanova, Z. K. (1990). Kazakhskoye slovo $v$ russkom literaturnom tekste [Kazakh word in Russian literary text]. Alma-Ata: Galym.

Kotkin, S. (2014). Stalin: Paradoxes of power, 1878-1928 (Vol. 1). New York, NY: Penguin Press.

Lambert, J. (2006). Literatures, translation and de(colonization). In D. Delabastita, L. D'Hulst, \& R. Meylaerts (Eds.), Functional approaches to culture and translation: Selected papers by J. Lambert 
(Vol. 89, pp. 87-104). Amsterdam: John Benjamins Publishing.

Levy, J. (1974). Iskusstvo perevoda [The art of translation]. Moscow: Publishing Progress.

François, G., Marácz, L., Pokorn, N. K., \& Kraus, P. A. (2018). Why should we combine different communication strategies? Paper presented at the MIME KickOff Conference, Geneva, Switzerland.

Nida, E. A. (1964). Toward a science of translating. Leiden: Brill Publishers.

Nikonova, N. E. (2008). Podstrochyi perevod: Tipologiya, funktsii i rol'v mezhkulturnoy kommunikatsii [Interlinear translation: Typology, functions and role in intercultural communication]. Tomsk: Tomsk State University.

Nurgaliyeva, A., Tastaeva, Z., Baibulsinova, A., \& Serikova, I. (2017). The Firecult and Islam in the Kazakh system of belief. Trames, 21(2), 151-160.

Ozhegov, S. I. (2012). Parshyvaya [Lousy]. Explanatory Dictionary of Russian Language. Retrieved from https://slovarozhegova.ru

Pieta, H. (2014). What do we (think) know about indirectness in literary translation? A tentative review of the state-of-the-art and possible research avenues. Punctum, 2014(199). Retrieved from https://repositorio. ul.pt/handle/10451/27791

Pieta, H. (2017). Theoretical, methodological and terminological issues in researching indirect translation: $\mathrm{A}$ critical annotated bibliography. Translation Studies, 10(2), 198-216.

Ringmar, M. (2007). "Roundabout routes": Some remarks on indirect translation. In F. Mus (Ed.), Selected papers of the CETRA research seminar in translation studies. Leuven: KU Leuven. Retrieved from https://arts.kuleuven.be/cetra/papers

Skrobonja, A., Kontosic, I., Basic, J., Vucevac-Bajt, V., Muzur, A., \& Golibovic, V. (2001). Domestic animals as symbols and attributes in Christian iconography: Some examples from Croatian sacral art. Veterinarni
Medicina, 46(4), 101-107.

Syzdykova, R. G., \& Khusain, K. S. (2001). Kamsol [Camisole]. In Kazakhsko-russkiyi slovar [KazakhRussian dictionary]. Almaty: Daik-Press.

Tuksaitova, R. O. (2007). Rechevaya tolerantnost' v bilingval'nom tekste (na material russkoyazychnoy kazakhskoy khudozhestvennoy prozy i publitsistiki) [Speech tolerance in a bilingual text (based on the material of Russian-language Kazakh fictional prose and journalism)] (Unpublished Doctoral dissertation). Ural State University, Yekaterinburg, Russia.

Tumanova, A. B. (2012). Spetsifika yazykovoy kartiny mira $v$ khudozhestvennom diskurse pisatelya-bilingva [The linguistic image of the world in the artistic discourse of a bilingual writer]. Vestnik RUDN, 2012(2), 38-44. Retrieved from http://journals.rudn.ru/semioticssemantics/issue/view/456

Witt, S. (2011). Between the lines: Totalitarism and translation in the USSR. In B. J. Baer (Ed.), Contexts, subtexts and pretexts: Literary translation in Eastern Europe and Russia (Vol. 89, pp. 149-170). Amsterdam: John Benjamins.

Witt, S. (2017). Institutionalized intermediaries: Conceptualizing Soviet practices of indirect literary translation. Translation Studies, 10(2), 162-182.

Woodsworth, J. (2013). Impact of translation. In Y. Gambier (Ed.), Handbook of translation studies (pp. 70-72). Amsterdam: John Benjamins.

Yelubay, S. (2008). Aq boz yui [White yurt]. Almaty: Atamura.

Yelubay, S. (2009). Odinokaya yurta [Lonely yurt]. Almaty: Izdatelstvo Audarma.

Yelubay, S. (2016). Lonely yurt. New York, NY: Metropolitan Classics.

Zhaksylykov, A. (2013). Adebi shygarmashylyq jane korkem audarma teoriyasy: Darister jinagy [Theory of literary creativity and literary translation: Collection of lectures]. Almaty: Kazakh University Press.

\section{About the Authors}

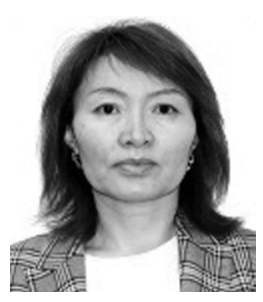

Aizhan Akkaliyeva is a Senior Teacher at Shakarim State University of Semey. She is a PhD candidate in Translation Studies at L. N. Gumilyov Eurasian National University and her research involves comparative analysis of translations of literary texts from Kazakh into Russian and English. She is also interested in cultural linguistics.

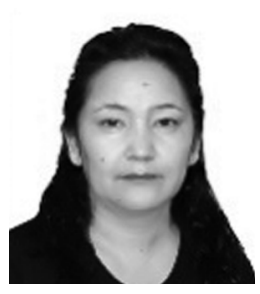

Baktigul Abdykhanova is an Associate Professor in the Department of Russian and Foreign Philology at Shakarim State University of Semey. Her areas of scientific interest include cognitive linguistics, pragmalinguistics, cultural linguistics, ethnolinguistics, intertextuality and translation issues. Her recent research involves precedent names in the Kazakh literary texts and the problems of their translation into foreign languages. 

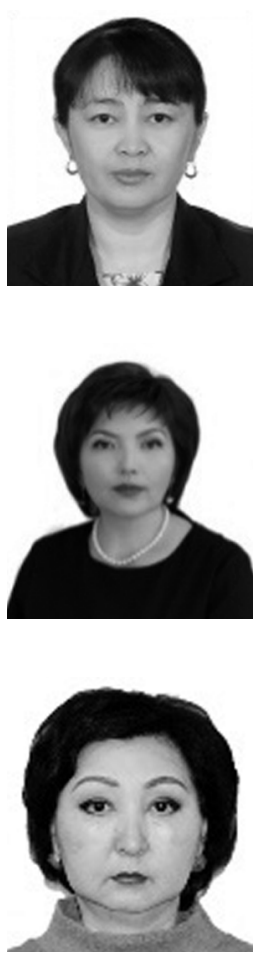

Lyazat Meirambekova is an Associate Professor at L. N. Gumilyov Eurasian National University and holds the Chair of Foreign Languages at the Faculty of International Relations in this institution. Her research interests lie in the realm of Turkish Studies. Her PhD dissertation specifically focuses on monosyllabic base of Kazakh and the Kipchak group languages.

Zhanar Jambayeva is a Professor of Philology in the Department of Theoretical and Applied Linguistics, at L. N. Gumilyov Eurasian National University. She has numerous publications on comparative and axiological linguistics, text linguistics and translation issues.

Galiya Tussupbekova is an Associate Professor in the Department of Kazakh Language and Literature, Philological Faculty, at the Shakarim State University of Semey. Her recent research publications cover the issues of axiological and cognitive linguistics, semantics of the Kazakh language. 